\title{
Targeting class I histone deacetylase 2 in MYC amplified group 3 medulloblastoma
}

\author{
Jonas Ecker ${ }^{1}$, Ina Oehme1, Ralph Mazitschek²,3, Andrey Korshunov ${ }^{4,5}$, Marcel Kool ${ }^{6,7}$, Thomas Hielscher ${ }^{8}$, \\ Judit Kiss ${ }^{1,9}$, Florian Selt ${ }^{1,9}$, Carina Konrad ${ }^{1}$, Marco Lodrini ${ }^{1,10}$, Hedwig E Deubzer ${ }^{1,9,10}$, Andreas von Deimling ${ }^{4,5}$, \\ Andreas E Kulozik' , Stefan M Pfister ${ }^{6,7,9}$, Olaf Witt ${ }^{1,9}$ and Till Milde ${ }^{1,9^{*}}$
}

\begin{abstract}
Introduction: Medulloblastoma (MB) is the most frequent malignant brain tumor in children. Four subgroups with distinct genetic, epigenetic and clinical characteristics have been identified. Survival remains particularly poor in patients with Group 3 tumors harbouring a MYC amplification. We herein explore the molecular mechanisms and translational implications of class I histone deacetylase (HDAC) inhibition in MYC driven MBs.

Material and Methods: Expression of HDACs in primary MB subgroups was compared to normal brain tissue. A panel of MB cell lines, including Group 3 MYC amplified cell lines, were used as model systems. Cells were treated with HDAC inhibitors (HDACi) selectively targeting class I or lla HDACs. Depletion of HDAC2 was performed. Intracellular HDAC activity, cellular viability, metabolic activity, caspase activity, cell cycle progression, RNA and protein expression were analyzed.

Results: HDAC2 was found to be overexpressed in MB subgroups with poor prognosis (SHH, Group 3 and Group 4) compared to normal brain and the WNT subgroup. Inhibition of the enzymatic activity of the class I HDACs reduced metabolic activity, cell number, and viability in contrast to inhibition of class Ila HDACs. Increased sensitivity to HDACi was specifically observed in MYC amplified cells. Depletion of HDAC2 increased H4 acetylation and induced cell death. Simulation of clinical pharmacokinetics showed time-dependent on target activity that correlated with binding kinetics of HDACi compounds.

Conclusions: We conclude that HDAC2 is a valid drug target in patients with MYC amplified MB. HDACi should cover HDAC2 in their inhibitory profile and timing and dosing regimen in clinical trials should take binding kinetics of compounds into consideration.
\end{abstract}

Keywords: Medulloblastoma, HDAC, HDAC inhibitor, HDAC2, MYC

\section{Introduction}

Medulloblastomas (MB) are the most frequent malignant brain tumors in children, with approximately 60 and 300 newly diagnosed cases per year in Germany and the US, respectively [1]. Brain tumors account for 38\% of cancer-related deaths, while leukemias account for $24 \%$ only despite having a much higher incidence [2]. Current treatment strategies for $\mathrm{MB}$ include aggressive

\footnotetext{
* Correspondence: t.milde@dkfz.de

${ }^{1}$ Clinical Cooperation Unit Pediatric Oncology (G340), German Cancer Research Center (DKFZ), Im Neuenheimer Feld 280, 69120 Heidelberg, Germany

${ }^{9}$ Section of Pediatric Brain Tumors, Department of Pediatric Oncology, Hematology and Immunology, University Hospital Heidelberg, Im Neuenheimer Feld 430, 69120 Heidelberg, Germany

Full list of author information is available at the end of the article
}

surgery, cranio-spinal irradiation and adjuvant chemotherapy dependent on a risk stratification, which until very recently was solely based on clinical features such as histology and presence or absence of metastates at the time of primary diagnosis (e.g. HIT 2000 trial in Germany). However, it has recently been recognized that MB comprises four distinct molecular subgroups termed WNT, SHH, Group 3 and Group 4 [3], and newly opened clinical trials, such as the SIOP PNET5 trial (NCT02066220), include molecular markers such as beta-catenin in their risk stratification. Both WNT and SHH groups have been classified based on their characteristic activated oncogenic pathways, yet much less is known about the drivers of Group 3 and $4 \mathrm{MB}[4,5]$. Importantly, the majority of Group 3 tumors are characterized by high protein levels 
of cMYC, either induced by $M Y C$ amplification or by aberrant $M Y C$ expression [6,7], and $M Y C$ amplification is a marker for high-risk in Group 3 [8].

Each molecular subgroup can be divided further into different subtypes based on characteristic molecular aberrations, with different clinical courses in $\mathrm{SHH}$, Group 3 and Group 4 [8], strongly suggesting additional biological heterogeneity in each subgroup. Indeed, the analysis of molecular biomarkers in individual subgroups reveals complex heterogeneity of $\mathrm{MB}$ subgroups down to the individual level, as has been shown for SHH [9] and Group 3 [10] MB. While the WNT and the SHH subgroups are characterized by several recurrent focal mutations in their respective determining pathways, recurrent mutations are unexpectedly rare in Group 3 and Group 4 tumors $[4,11,12]$. However, several mechanisms of structural variation are recurrent in Group 3 and Group 4 tumors, including somatic copy number alterations, chromothripsis and tetraploidy $[13,14]$, as well as a newly recognized mechanism termed enhancer hijacking that leads to aberrant oncogene expression [10].

More recently it has become evident that a driving element in Group 3 and Group 4 MBs are aberrations of genes associated with chromatin modification [5,15]. Most of these genes encode for histone mark reader proteins or members of chromatin modifying enzyme complexes, such as KDM6A [4], MLL2 [11], ZMYM3 and CHD7 [12]. Somatic mutations, as well as aberrant expression and somatic copy number variations of chromatin modulators lead to altered H3K4 and H3K27 methylation profiles in Group 3 and Group 4 tumors [16]. Finally, the novel MB candidate driver gene LIN28B was identified in Group 3 and $4 \mathrm{MB}$ solely based on aberrant DNA methylation and overexpression of an alternative transcript [17].

While much insight has been gained into the relevance and function of histone methylation-dependent epigenetic events in Group 3 and Group $4 \mathrm{MB}$, much less is known about lysine acetylation- (or HDAC-) dependent epigenetic aberrations in $\mathrm{MB}$ at a chromatin-wide level. The zinc-dependent HDAC1 through HDAC11 comprise 11 members grouped into four classes (I, IIa, IIb, and IV) [18]. In SHH MBs, SHH-induced HDAC activity is required for continued proliferation of cerebellar granule precursor cells [19]. We and others have previously shown that HDACi treatment exerts anti-tumoral effects in $\mathrm{MB}$ in vitro and in vivo [20-24]. Our group has shown that distinct HDAC family members control specific oncogenic functions in pediatric neuronal cancer models including differentiation, cell cycle regulation, apoptosis, autophagy, chemotherapy resistance $[25,26]$, and alterations in tumor suppressor pathways $[27,28]$.

We have further demonstrated that specific HDAC isoforms are differentially expressed in MB [29,30], and found that expression of class IIa HDACs 5 and 9 correlates with cytogenetic aberrations and poor clinical outcome in the entire cohort of MB tumors, and high HDAC2 expression in group $3 \mathrm{MBs}$ [30]. With the recent advent of class-selective HDAC inhibitors (HDACis), such as the class IIa-selective HDACis MAZ1863 and MAZ1866 [31] and selective substrates has opened the possibility of class-selective exploration of HDAC biology.

The aim of the presented study is to investigate the selective targeting of HDAC family members in a MB subgroup specific manner, and to elucidate the translational consequences.

\section{Materials and methods}

\section{Patients and clinical samples}

Material from patients of tissue microarray (TMA) set (paraffin embedded medulloblastoma samples) were randomly collected at the Department of Neuropathology, Burdenko Neurosurgical Institute (Moscow, Russia) between 1993 and 2011. Approval to link laboratory data to clinical data was obtained by the Institutional Review Board. Two neuropathologists confirmed the diagnoses according to the $2000 \mathrm{WHO}$ classification. None of the patients had received irradiation or chemotherapy before collection of specimens. Metastatic state (M stage) was determined by magnetic resonance imaging and cerebro- spinal fluid cytopathology at diagnosis. Clinical and histopathologic data are summarized in Additional file 1: Table S1.

\section{Cell lines, cell culture and siRNA-mediated knockdown}

Cell lines and cell culture conditions have been described previously: MED8A, UW228-2, ONS76 and DAOY in [29], HD-MB03 in [24], D458 in [32]. All cell lines had their identity confirmed and proven to be free of contamination by mycoplasma or viral contamination using the Multiplex cell Contamination Test $(\mathrm{McCT})$ service [33]. MYC status of all cell lines was confirmed by fluorescent in-situ hybridization (see below). siRNA transfection was performed as reported previously [29]. siRNA reagents were purchased from Qiagen (Hilden, Germany) (see Additional file 2: Table S2).

\section{RNA-isolation, CDNA synthesis, quantitative reverse transcription real-time PCR (qPCR) and gene expression analysis}

RNA extraction, cDNA synthesis, quantitative real-time PCR, and software analysis was performed as reported previously [29]. Primers were purchased from Qiagen (see Additional file 3: Table S3). Normal cerebellum RNA was purchased from Clontech (Mountain View, CA, USA).

The database analysis tool R2 (http://r2.amc.nl) was used to investigate HDAC1, 2, and 3 mRNA expression in brain tumors and normal brain tissues using 
publicly available datasets (Dataset: [7], Probesets: HDAC1 (201209_at), HDAC2 (201833_at), HDAC3 (216326_s_at).

\section{Western blot (WB) and image processing}

Protein concentrations of cell lysates were determined using the Thermo Scientific Pierce (Waltham, MA, USA) BCA Protein Assay Kit according to manufacturer's instructions. The following antibodies were used: monoclonal mouse anti-human cMYC (1:200, catalog no. sc-40; Santa Cruz, Dallas, TX, USA), monoclonal mouse antihuman HDAC2 (1:1000; catalog no. sc-81599; Santa Cruz), polyclonal rabbit anti-human AcH4 (1:1000; catalog no. 06-866; Milipore, Billerica, MA, USA) and mouse monoclonal anti- $\beta$-actin (1:10000; catalog no. A5441; SigmaAldrich) and detected with Amersham ECL Prime Western Blotting Detection System (GE Healthcare, Little Chalfont, UK) on PVDF membrane with ChemiSmart 5000 Technology (Vilber Lourmat, Eberhardzell, Germany). Uncropped images were contrast enhanced with Chemi-Capt 5000 (Vilber Lourmat) and subsequently cropped in Microsoft Office PowerPoint 2007 SP3 (Microsoft Corporation, Redmond, WA, USA).

TMA, IHC, and fluorescent in-situ hybridization (FISH) DNA and RNA was extracted from the original tumors included in this TMA and analyzed by nanoString [34] and/ or $450 \mathrm{k}$ Array [35] as described previously to assign the molecular subgroups. For preparation of the TMA and IHC, see [36]. For detection of HDAC2, the antibody No. ab32117 [Y461] (Abcam, Cambridge, UK) was used at 1:250 dilution. IHC was performed as reported previously [37]. The scoring of the IHC was performed by two investigators (JE and TM), who were both blinded to the clinical information. Four staining intensity levels were defined and weightened with 0 for no staining, 1 for weak staining, 2 for intermediate staining and 3 for strong staining. The $\mathrm{H}$-Score was calculated by summation of the percentages of area stained at each intensity level multiplied by the weightened intensity (i.e. $0,1,2$, or 3) [38]. The arithmetic mean of the scoring of both investigators was calculated.

MYC status of all cell lines was verified by FISH, as described previously [39]. The probe used was Vysis LSI MYC (Cat. No.: 03 N87-020, Abbott, Abbott Park, IL, USA).

\section{Microscopy}

Bright-field images as well as IHC images were captured using an Olympus CX41 microscope with a Color View camera, and CellB 2.3 software (Olympus, Shinjuku, Tokyo, Japan).

\section{HDAC inhibitors (HDACis)}

Class IIa HDACis MAZ1863 (compound 6) and MAZ1866 (compound 13) have been described previously [31].
MAZ1863 and MAZ1866, vorinostat (suberoylanilide hydroxamic acid, SAHA; Cat. No. S1047, Selleck Chemicals, Houston, TX, USA), and MS-275 (Cat. No. M4693-15A.25, Biomol GmbH, Hamburg, Germany) were dissolved in DMSO. HDACi and solvent controls were diluted in cell culture medium and added to the cell culture medium to achieve the indicated concentrations.

\section{HDAC activity assay and washout experiments}

$0.5 \times 10^{*} 5$ cells in $100 \mu \mathrm{l}$ medium were seeded in a 96well plate and incubated for 24 hours at $37^{\circ} \mathrm{C}, 5 \% \mathrm{CO}_{2}$. The artificial class I HDAC substrate Boc-Lys(Ac)-AMC (Cat. No. 1875, Bachem, Bubendorf, Switzerland), or class IIa HDAC substrate Boc-Lys(trifluoroacetyl)-AMC (Cat. No. 1985, Bachem) reconstituted in DMSO were diluted in cell culture medium for a final concentration of $50 \mu \mathrm{M}$. The developer solution was prepared with a working concentration of $2.5 \mathrm{mg} / \mathrm{ml}$ trypsin from porcine pancreas in DMEM, $2 \%$ of TritonX-100 and $10 \mu \mathrm{M}$ of Trichostatin-A (TSA) and stored on ice until usage. Cell culture media was carefully removed and cells were treated with varying concentrations of HDACi $(25 \mu \mathrm{l} /$ well). After 5 min incubation at room temperature $25 \mu \mathrm{l}$ of substrate dilution were added. After $30 \mathrm{~min}$ incubation at $37^{\circ} \mathrm{C} 50 \mu \mathrm{l}$ of developer solution were added. After $30 \mathrm{~min}$ incubation at $37^{\circ} \mathrm{C}$ emitted fluorescence was measured in the plate reader FLUOstar OPTIMA (BMG Labtech, Ortenberg, Germany), and analyzed with OPTIMA Software, Version 2.00 R3 (Labtech).

For washout experiments cells were seeded as described above. After 24 hours incubation at $37^{\circ} \mathrm{C}$ the medium was carefully removed and the cells were treated with a dilution of an HDAC inhibitor and incubated at $37^{\circ} \mathrm{C}$. After 90 minutes the inhibitor was carefully removed from the cells and cells were washed three times with $200 \mu \mathrm{l}$ of fresh medium. At timepoints $0 \mathrm{~h}$, $1 \mathrm{~h}, 3 \mathrm{~h}, 6 \mathrm{~h}, 12 \mathrm{~h}$ and $24 \mathrm{~h}$ after inhibitor removal HDAC activity was measured as described above.

\section{Metabolic activity assay, cell counts and analysis of viability}

The WST-1 assay (Roche, Basel, Switzerland) was used for the metabolic activity assays, these were performed as described [40]. Cell counts and analysis of viability by trypan blue exclusion staining were performed using a ViCell XR counter (Beckman Coulter, Brea, CA, USA).

\section{Measurement of the sub-G0 fraction and caspase-3-like activity}

The sub-G0 fraction and caspase-3-like activity was measured as described [29]. The positive control for the caspase-3-like activity consisted of untransfected cells treated with UV light $\left(35 \mathrm{~mJ} / \mathrm{cm}^{2}\right) 12 \mathrm{~h}$ before caspase3-like activity measurement. 


\section{Statistics analysis and graph editing}

In vitro experiments were performed in a minimum of three biological replicates. Half-maximal effective concentrations $\left(E_{50}\right)$ of HDACi were calculated using GraphPad Prism version 5.01 (GraphPad Software, La Jolla, CA, USA) for Windows. Results of treatments were compared using an unpaired t-test or One Way ANOVA test with Bonferroni's multiple Comparison Test as indicated. pvalues $<0.05$ were considered significant. Graphs were generated using GraphPad Prism version 5.01 and Microsoft Powerpoint for Mac 2011, Version 14.4.5.

\section{Results}

\section{MYC amplified medulloblastomas display differential}

\section{expression of class I HDACs}

We have previously shown that differential expression of HDAC family members occur in medulloblastoma. Whereas class IIa HDACs 5 and 9 correlate with specific cytogenetic aberrations and poor clinical outcome in the entire cohort of MB tumors [29], analysis of MB subgroup specific expression revealed a particular high level of HDAC2 in all three subgroups of MB associated with higher risk, i.e. $\mathrm{SHH}$, group 3 and group 4 [30].

Since target expression in the respective tissue is a prerequisite for targeted treatment, we examined the expression of class I HDACs in primary tissues. In a first step, we investigated mRNA expression levels of class I HDACs $H D A C 1,2$ and 3 in primary MB samples. $H D A C 2$ was most abundantly expressed in MB (WNT: 296.2 - 742.4 AUs, SHH: 720.1 - 2190.1 AUs, Group3: 611.6 - 2847.6 AUs, Group4; 546.2 - 2007.1 AUs), compared to HDAC1 (WNT: 179.3 - 436 AUs, SHH: 22.7 - 481.1 AUs, Group3: 22.2 - 514.3 AUs, Group4 4.4 - 184.9 AUs) and HDAC3 (mean of WNT 21.6 - 103.3 AUs, SHH 13.7 - 118.1 AUs, Group3 30.9 - 123,5 AUs, Group4 23.9 - 116 AUs) (Figure 1a), with highest expression of $H D A C 2$ mRNA in subgroups with poor prognosis ( $\mathrm{SHH}$, Group 3 and 4), while both WNT and normal cerebellum

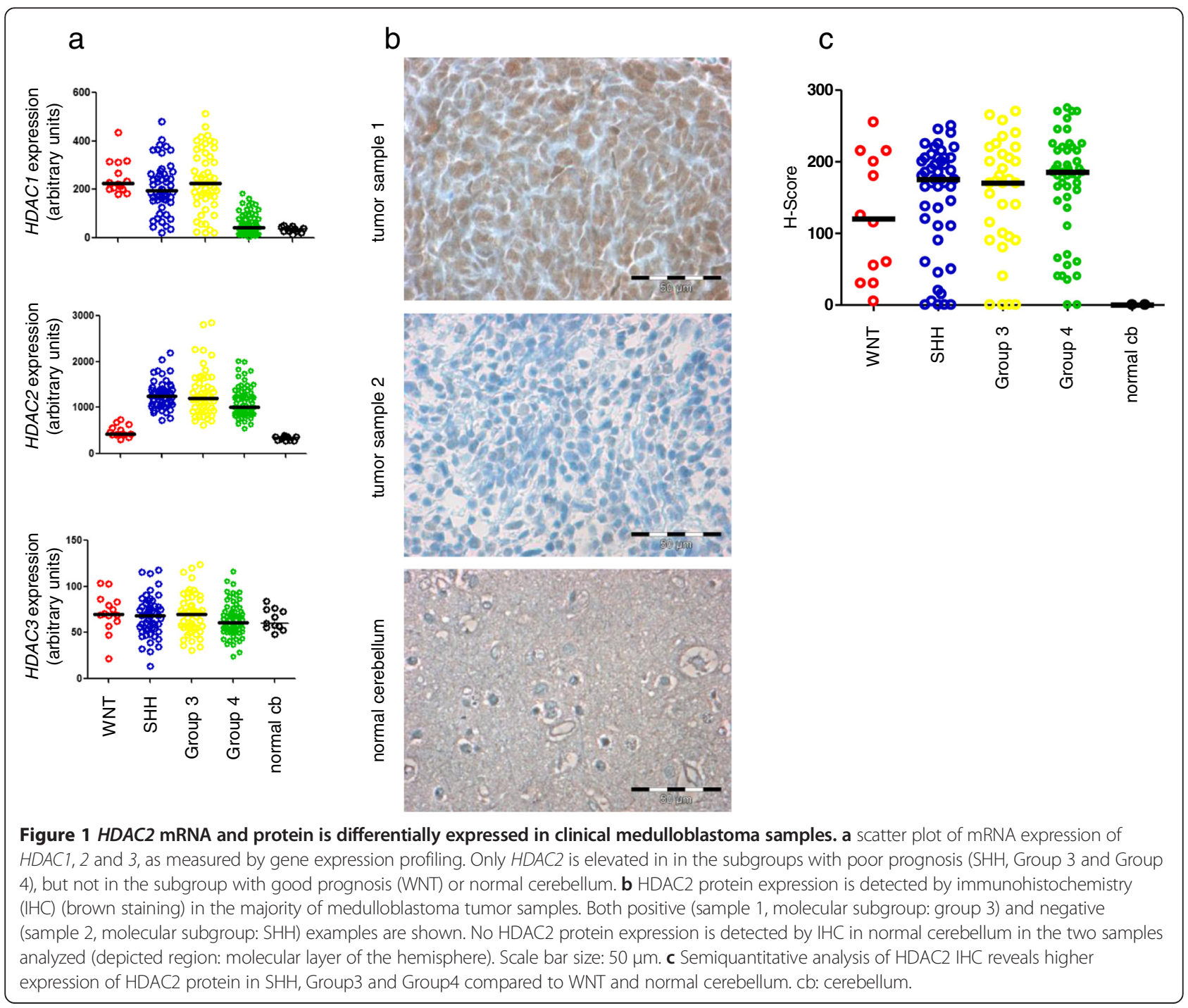


showed low expression of $H D A C 2$ (Figure 1 a). In contrast, HDAC1 mRNA displayed similar levels in subgroups with highly disparate prognoses (WNT and SHH/Group3), and at higher levels in WNT, SHH, and Group 3 than in Group 4 and normal cerebellum (Figure 1a, upper panel). Finally, HDAC3 was expressed at relatively low but similar levels in all four molecular subgroups and normal cerebellum (Figure 1a, lower panel). HDAC2 therefore displays the most differential expression pattern in the respective subgroups and is highly expressed in subgroups with overall poor clinical prognosis. In contrast both $H D A C 1$ and 3 expression shows little or no correlation to subgroup prognosis. We therefore focused on HDAC2 in the following analyses. To evaluate protein expression of the putative target HDAC2 in a large set of primary MB tumor samples, we performed immunohistochemistry (IHC) for HDAC2 on a tissue microarray (TMA) with $\mathrm{n}=142 \mathrm{MB}$ samples (Figure 1b). Each sample was scored for HDAC2 staining using the H-Score in a blinded manner by 2 independent investigators. $\mathrm{SHH}$, Group 3 and Group 4 MBs exhibited a higher H-Score compared to WNT and normal cerebellum (Figure 1c). In summary HDAC2 appears to be the most promising target within the tested class I HDACs, and HDAC2 protein is highly expressed in molecular groups with poor prognosis, including Group 3 which includes most of the $M Y C$ amplified cases.

To investigate how well the MB cell lines used in our studies resemble the molecular biology of primary tumors we compared HDAC1, 2 and 3 and MYC gene and protein expression levels. Increased expression of both $M Y C$ mRNA and cMYC protein was confirmed in cell lines with $M Y C$ amplification by RT-qPCR and WB, respectively (Figure 2a, b). Similar to Group 3 MB tumors [30], the MYC amplified cell lines HD-MB03, MED8A, and D458 express elevated levels of class I HDACs 1,2,3
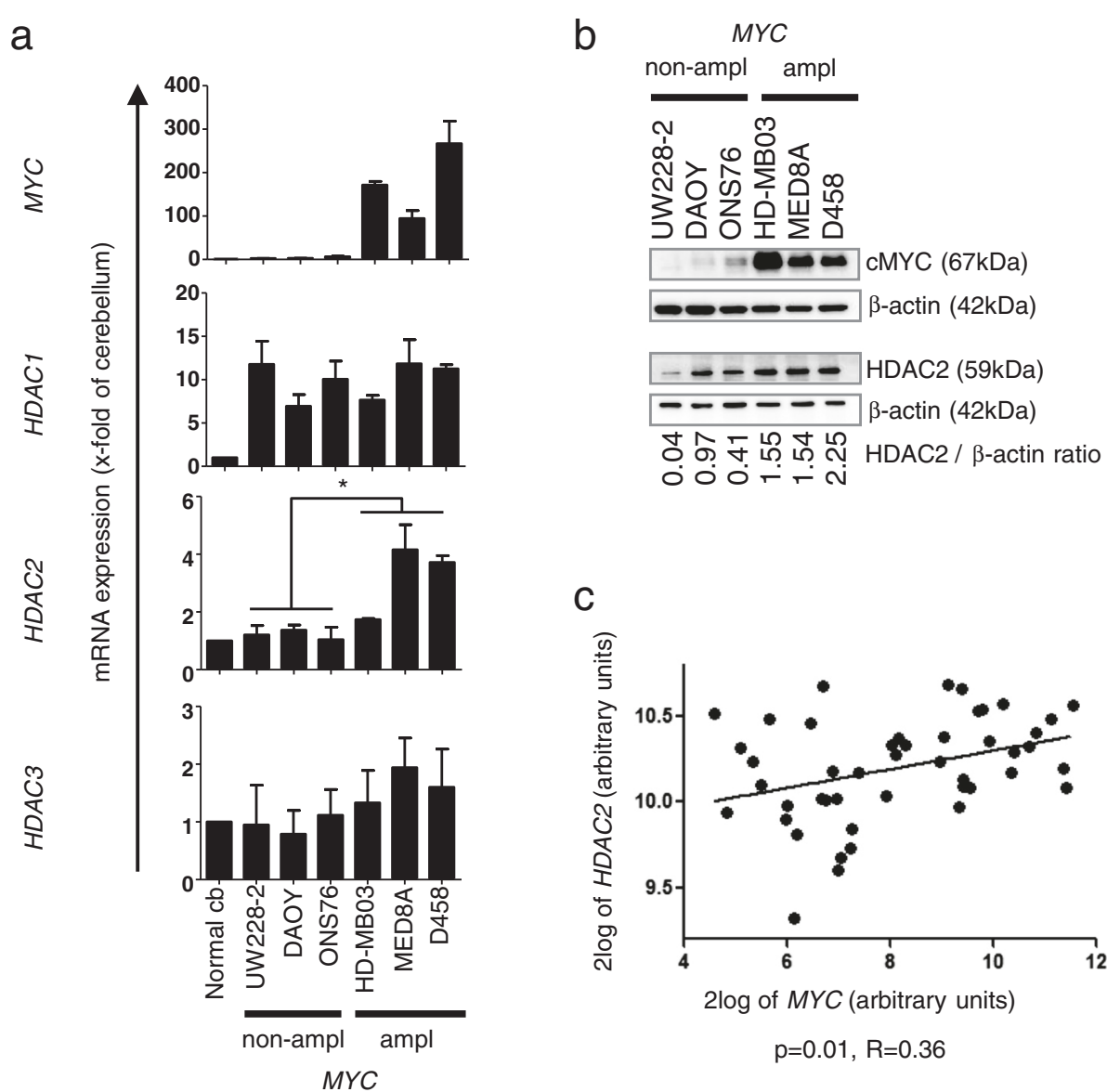

Figure 2 MYC amplified medulloblastoma cell lines show differential expression of class I HDACs HDAC1, 2 and 3. a gene expression as measured by quantitative RT-real time PCR shows differential expression of HDAC1, 2 and 3 in medulloblastoma cell lines with high MYC expression, with HDAC2 showing a significant difference between MYC amplified and MYC non-amplified cell lines ( ${ }^{*}=p<0.05$, one way ANOVA test). $\mathbf{b}$ protein detection by western blot detects higher CMYC and HDAC2 protein in cells with MYC amplification. c correlation of HDAC2 and MYC mRNA expression as measured by gene expression profiling in $n=42$ primary Group 3 MB tumors (Pearson product-moment correlation coefficient, two tailed p-test). Bars depict mean and standard error of three independent experiments. 
mRNA relative to normal cerebellum (Figure 2a). Additionally, only $H D A C 2$ showed a significant differential expression between $M Y C$ amplified compared to nonamplified cells (Figure 2a), which was confirmed on the protein level by western blot (Figure 2b). This correlation between $M Y C$ and $H D A C 2$ mRNA expression can also be found in primary Group $3 \mathrm{MBs}$ in a series of $n=$ 42 tumors (Figure 2c), GEO ID GSE37382 [14]. We conclude that the MYC amplified cell lines HD-MB03, MED8A, and D458 reflect the molecular biology of $M Y C$ amplified Group $3 \mathrm{MBs}$, with regard to expressing high levels of class I HDAC2, and thus are good models to study the function of HDAC2 in this subgroup.

\section{Inhibition of class I but not class Ila HDAC catalytic} activity affects $M Y C$ amplified medulloblastoma cells

To determine the functional oncogene dependency of $\mathrm{MB}$ cells to particular HDAC family members, we investigated the consequences of targeting HDAC enzymatic activity on $\mathrm{MB}$ cell survival in an isoform-selective manner. To this aim, we tested the ability of vorinostat (targeting class I and class IIb HDACs) [41] versus MAZ1863 and MAZ1866 (targeting class IIa HDACs) [31] to inhibit intracellular HDAC acitivity using class-specific substrates in a cell-based in vitro assay (Figure 3). As expected [41], vorinostat efficiently blocked class I/IIb enzymatic HDAC activity in MED8A MB cells (Figure 3, black bars), but not class IIa HDAC enzymatic activity (Figure 3, white bars). Vice versa, class IIa selective compounds MAZ1863 and MAZ1866 efficiently blocked intracellular class IIa HDAC enzymatic activity (Figure 3, white bars) but not classI/IIb HDAC activity (Figure 3, black bars). After having shown that $\mathrm{MB}$ cells harbor measurable intracellular class I, IIa, and IIb HDAC enzymatic activity that can selectively be blocked through small molecule inhibitors, we evaluated the anti-tumoral effect of HDACis with different HDAC isoform selectivity profiles (MAZ1863, MAZ1866, vorinostat and MS-275) on MB cells, we profiled MB cell lines with and without $M Y C$ amplification in a metabolic activity assay. After $72 \mathrm{~h}$ of treatment with HDACis, only very weak effects on metabolic activity could be observed for class IIa HDACis MAZ1863 and MAZ1866, both in MYC amplified and non-amplified MB cells (Figure 4a). In contrast, HDACis vorinostat (prefentially inhibiting class I/IIb HDACs) [41] or the class I specific inhibitor MS-275 (selctively inhibting HDAC1, 2, and 3) [41] greatly

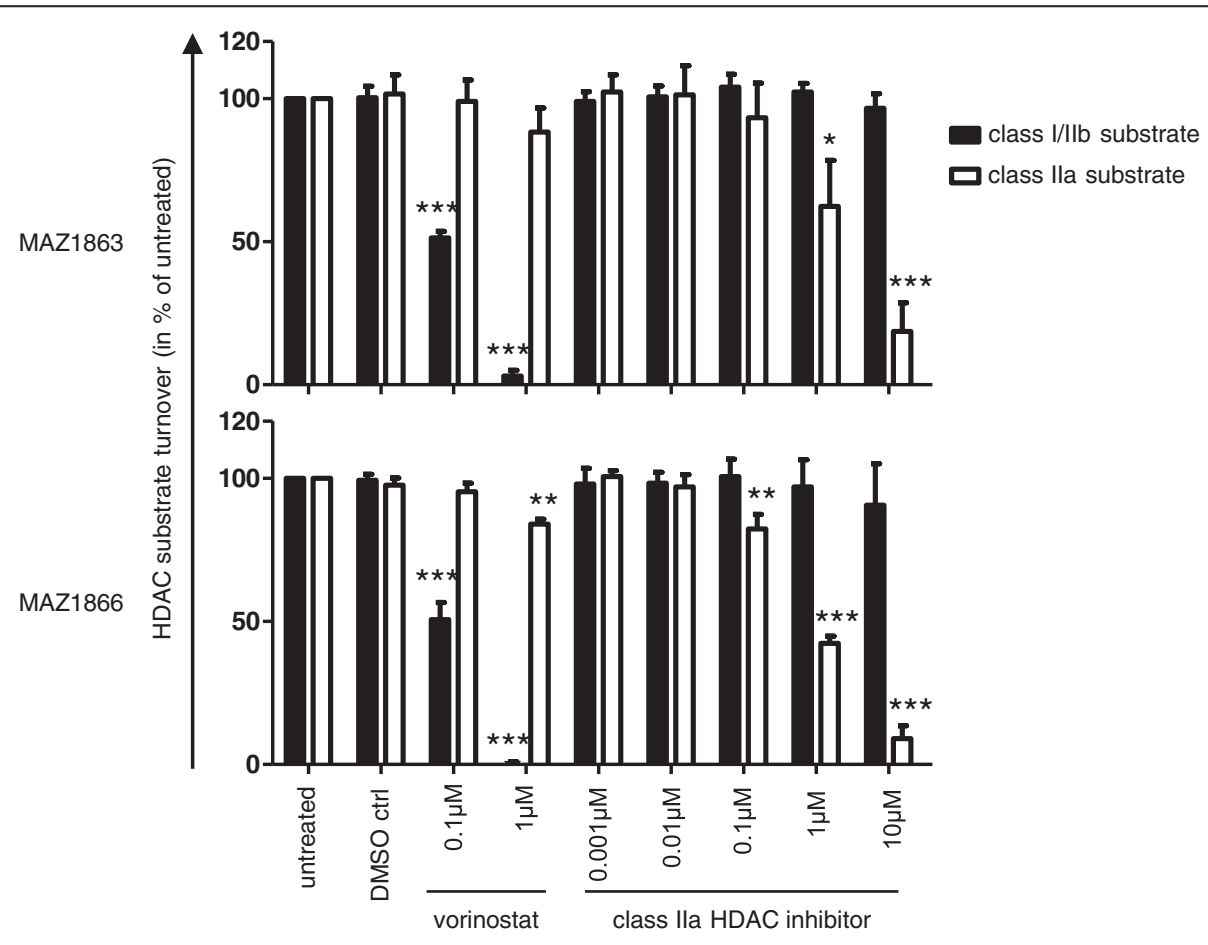

Figure 3 HDAC inhibitors MAZ1863 and MAZ1866 are highly selective and potently inhibit class lla activity. Both MAZ1863 (top) and MAZ1866 (bottom) significantly inhibit intracellular class Ila HDAC activity compared to DMSO control, as measured by class lla HDAC specific substrate turnover in a cell-based biochemical HDAC activity assay after treatment of MED8A MB cells with the compounds at indicated concentrations for $1 \mathrm{~h}$. Class I/llb HDAC activity is not inhibited by MAZ1863 or MAZ1866, while vorinostat significantly inhibits class I/llb HDAC activity, as expected. Bars depict mean and standard error of three independent experiments, significant differences compared to DMSO control are indicated: ${ }^{*}=p<0.05,{ }^{* *}=p<0.01,{ }^{* * *}=p<0.001$ (unpaired t-test). 


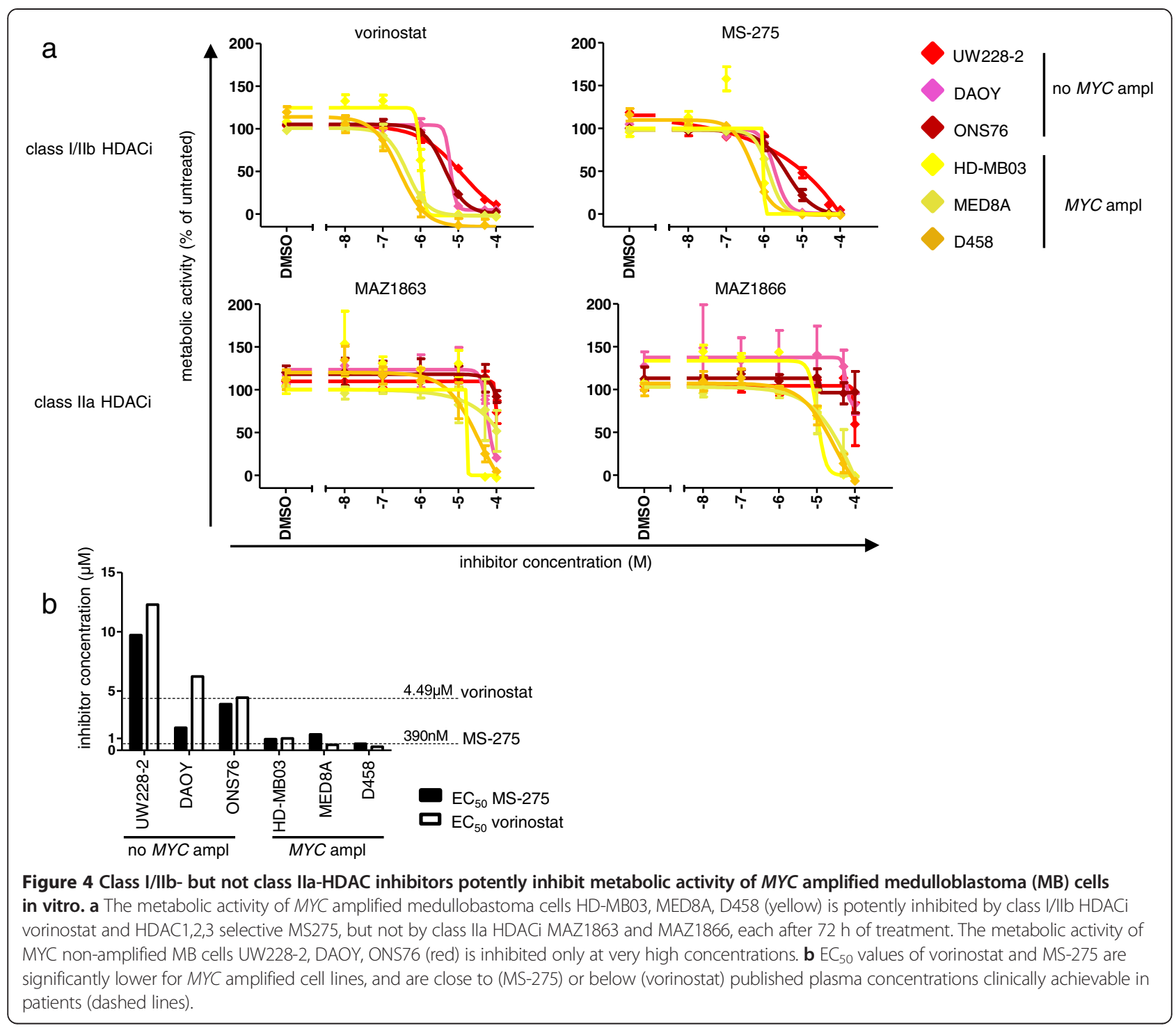

reduced metabolic activity in both $M Y C$ amplified and non-amplified MB cells (Figure 4a). However, comparison of the dose-dependent inhibition of metabolic activity by vorinostat and MS-275 for each cell line revealed a strong difference between $M Y C$ amplified and non-amplified MB cells, with $\mathrm{EC}_{50}$ values for $M Y C$ amplified cells within the range of published clinically achievable peak plasma concentrations (Figure 4b; Additional file 4: Table S4) $(4,49 \mu \mathrm{M}$ for vorinostat [42] and $390 \mathrm{nM}$ for MS-275 [43]). Accordingly, after treatment for $72 \mathrm{~h}$ both the number as well as the viability of cells was significantly reduced in MYC amplified cells (MED8A, HD-MB03) compared to a $M Y C$ non-amplified cell line (UW228-2) (Figure 5). These results suggest that inhibition of class IIa activity has only a minor impact on MB tumor cell survival, whereas inhibition of class I enzymes HDAC1, 2 and 3 elicits a strong response in $M Y C$ amplified MB cells.

\section{HDAC2 depletion induces cell death and attenuates cell growth}

To investigate the effect of loss of HDAC2 function on tumor biology, we performed siRNA-mediated knockdowns of HDAC2 in MYC amplified cells. Knockdown with three different siRNAs against HDAC2 reduced HDAC2 protein, and increased acetylation of histone H4 $72 \mathrm{~h}$ after knockdown (Figure 6a). Caspase 3-like activity was increased $72 \mathrm{~h}$ after knockdown (Figure $6 \mathrm{~b}$ ), both increasing the sub G0/G1 fraction (Figure 6c) and reducing the number of viable cells (Figure 6d) $96 \mathrm{~h}$ after knockdown. We therefore conclude that siRNA- 


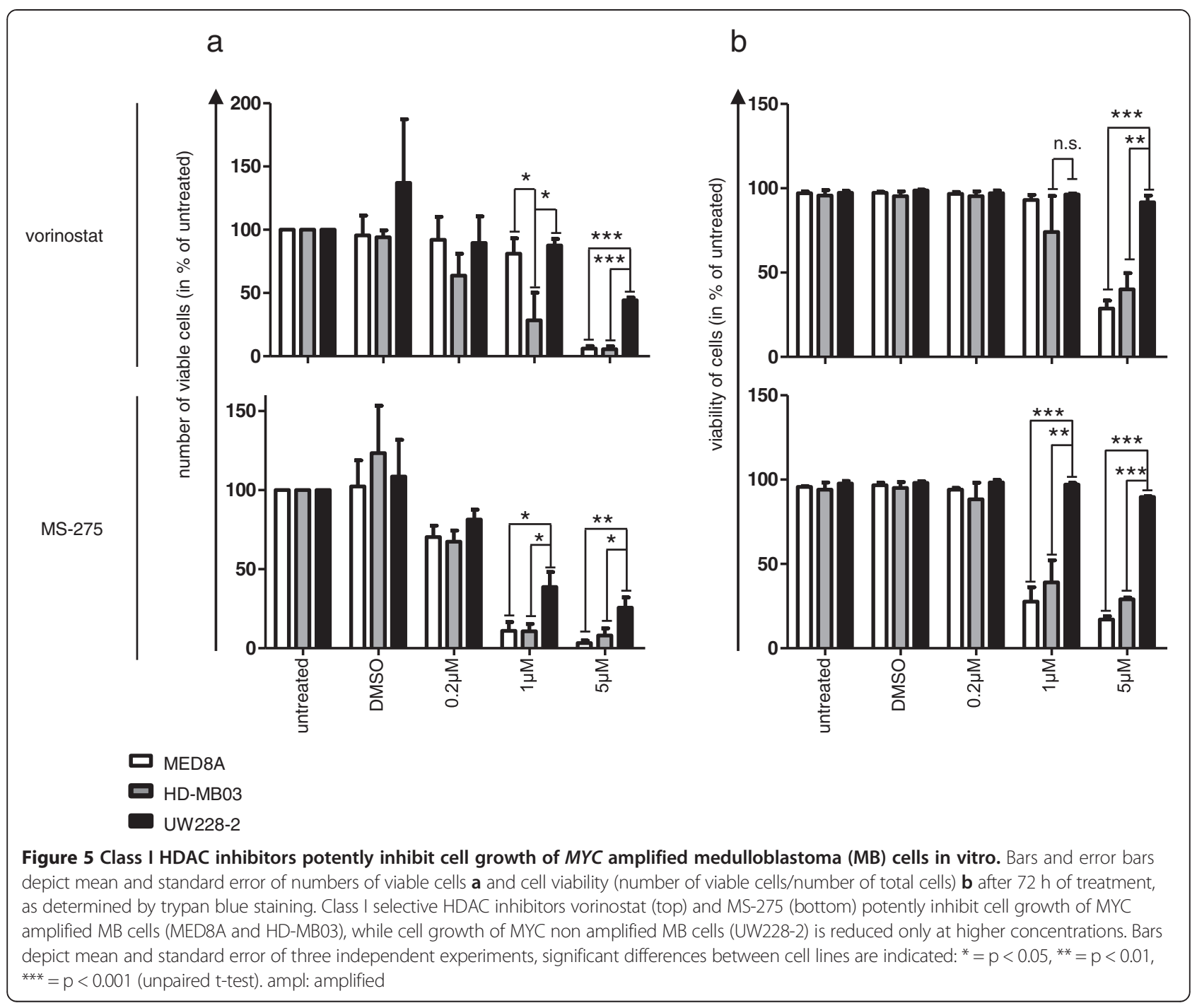

mediated depletion of HDAC2 protein induces cell death and reduces cell growth.

\section{Simulation of clinical pharmacokinetics of HDACi in vitro uncovers challenges for translation}

Despite the well-established pre-clinical effects of HDAC inhibitors on differentiation, cell cycle, apoptosis, autophagy, chemotherapy resistance $[25,26]$, as well as alterations of tumor suppressor pathways [27,28], clinicial trials have so far failed to demonstrate a significant antitumoral effect of HDACis in solid malignancies [44,48], in contrast to leukemias and lymphoma. One potential explanation concerns the very short in vivo half-life of some compounds including vorinostat with a plasma half-life of 90 minutes only [49], leaving the tumor unexposed to the compound for most of the time when dosed once per day. In classical cell culture models, however, cells are exposed to HDACi $24 \mathrm{~h}$ /day in vitro. To model the in vivo plasma half-life in our in vitro cell culture model, we performed wash-out experiments in vitro, simulating the in vivo conditions of a once per day vorinostat application. After incubation with either vorinostat or MS-275, intracellular class I/IIb HDAC activity was measured at regular intervals, starting immediately after the washout, and a setting with no washout served as controls. Vorinostat immediately and strongly suppressed HDAC activity in the setting with no washout (Figure 7a), demonstrating immediate inhibition of class I HDACs. MS-275 similarly suppressed HDAC activity only in a time-dependent manner, i.e. a level of suppression similar to vorinostat was only achieved after $12 \mathrm{~h}$ (Figure 7a), suggesting a slow inhibition kinetic of MS-275, as has already been shown for aminoanilide/ benzamide based inhibitors [50]. In the washout setting, strikingly, the inhibition of HDAC activity by vorinostat was immediately lost after the washout, suggesting very fast binding kinetics and dissociation of the inhibitor from its target. MS-275 however did still inhibit HDAC 


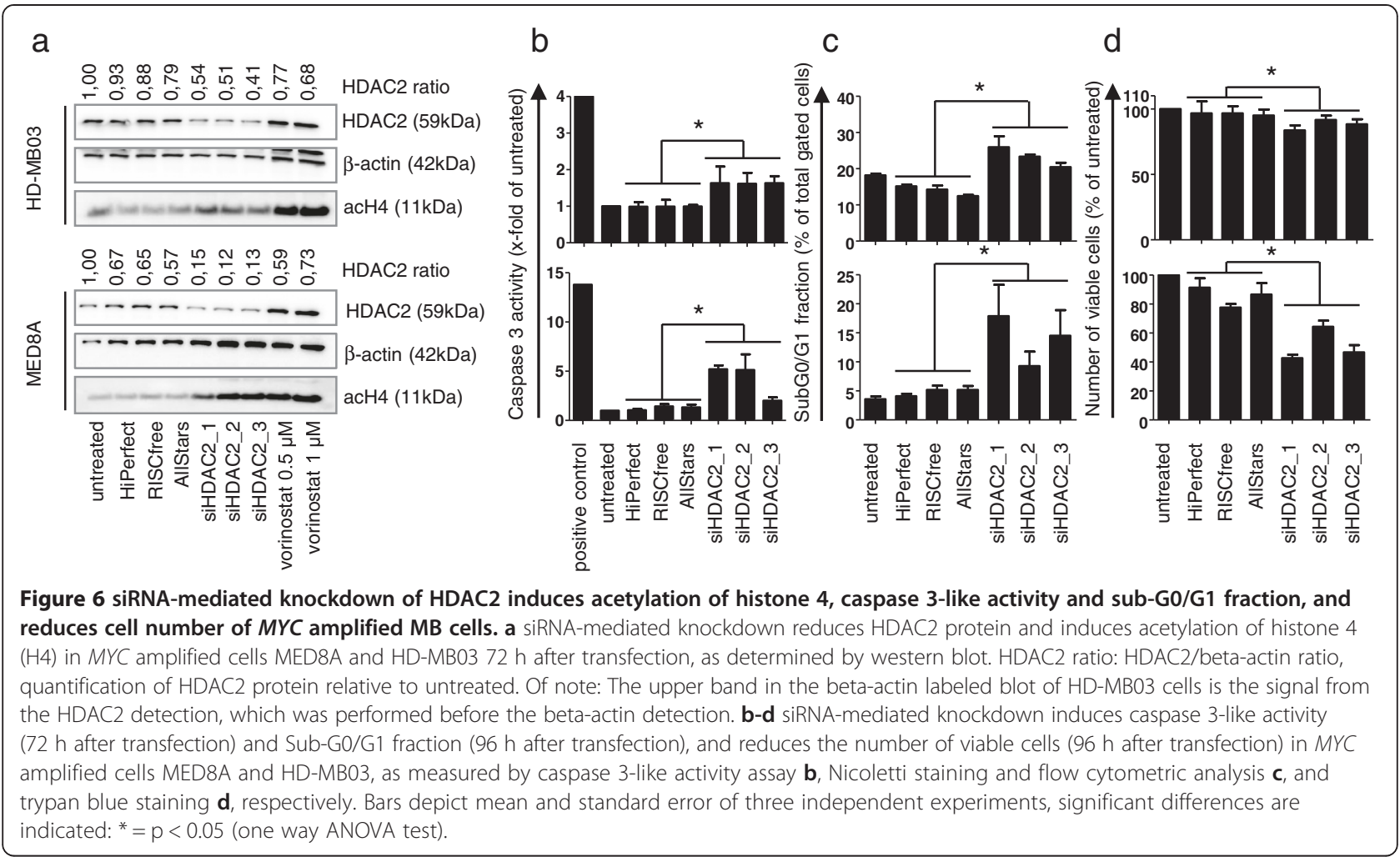

activity after washout, similar to the level in the no washout setting at $0 \mathrm{~h}$, with only a slow recovery of HDAC activity (Figure 7a), again suggesting slow binding kinetics. Accordingly, in the analysis of downstream epigenetic effects by WB of acetylated histone $\mathrm{H} 4$, we found an immediate and lasting hyperacetylation of $\mathrm{H} 4$ following vorinostat treatment in the no washout setting, which was rapidly reduced in the washout setting (Figure $7 \mathrm{~b}$ ). Conversely, the hyperacetylation of $\mathrm{H} 4$ in response to MS-275 treatment increased over time with almost no immediate hyperacetylation, but a long lasting effect even in the washout setting, i.e. hyperacetylation of $\mathrm{H} 4$ can still be found $6 \mathrm{~h}$ after washout (Figure 7b). Analysis of antitumoral efficacy as determined by metabolic activity after $72 \mathrm{~h}$ showed a strong effect in the no washout setting for both vorinostat and MS-275, as previously shown (Figure $7 \mathrm{c}$ ). However, if the cells were incubated once per $24 \mathrm{~h}$ for $90 \mathrm{~min}$ followed by a washout, simulating the clinical situation of once per day (qd) vorinostat application in a patient, no reduction of metabolic activity was seen for vorinostat, and only at a very high concentration of $10 \mu \mathrm{M}$ for MS-275 (Figure 7c). In summary, vorinostat has a strong but short-lived inhibitory effect on HDAC activity, with a brief downstream effect on the epigenetic target $\mathrm{H} 4$ under simulated clinical conditions, which is reflected by no detectable effect on metabolic activity. MS-275 has a moderate but longer-lived effect on HDAC activity, with a lasting downstream effect on the epigenetic target H4 under simulated clinical conditions. This however translates into reduction of metabolic activity only at very high MS-275 concentrations, which are clinically not achievable. These findings suggest a clinically relevant correlation between a compound's binding kinetics and its on-target activity.

\section{Discussion}

Successful treatment of MB remains a challenge in many patients, which suffer from therapy-related side effects, and the prognosis remains poor for many patients with Group $3 \mathrm{MB}$ [13]. Based on reports suggesting that epigenetic events seem to play an important role in this subgroup, we have investigated the selective targeting of HDAC family members in a subgroup specific manner.

We have previously found that the class IIa isoforms HDACs 5 and 9 are widely expressed on the protein level, and relatively overexpressed on the mRNA level in $\mathrm{MB}$ with poor prognosis (Chr 6q gain or 17q gain) [29]). Depletion of either HDAC5 or HDAC9 protein in MB cells resulted in a reduction of cell proliferation and increase in cell death [29]. To investigate whether inhibition of the enzymatic deacetylase activity can phenocopy these effects, we tested novel selective class IIa HDAC inhibitors. Although these inhibitors strongly inhibited class IIa enzymatic activity in MB cells in dose-dependent fashion, we did not observe any obvious biological effect, such as reduction of metabolic activity in MB cells. These results 


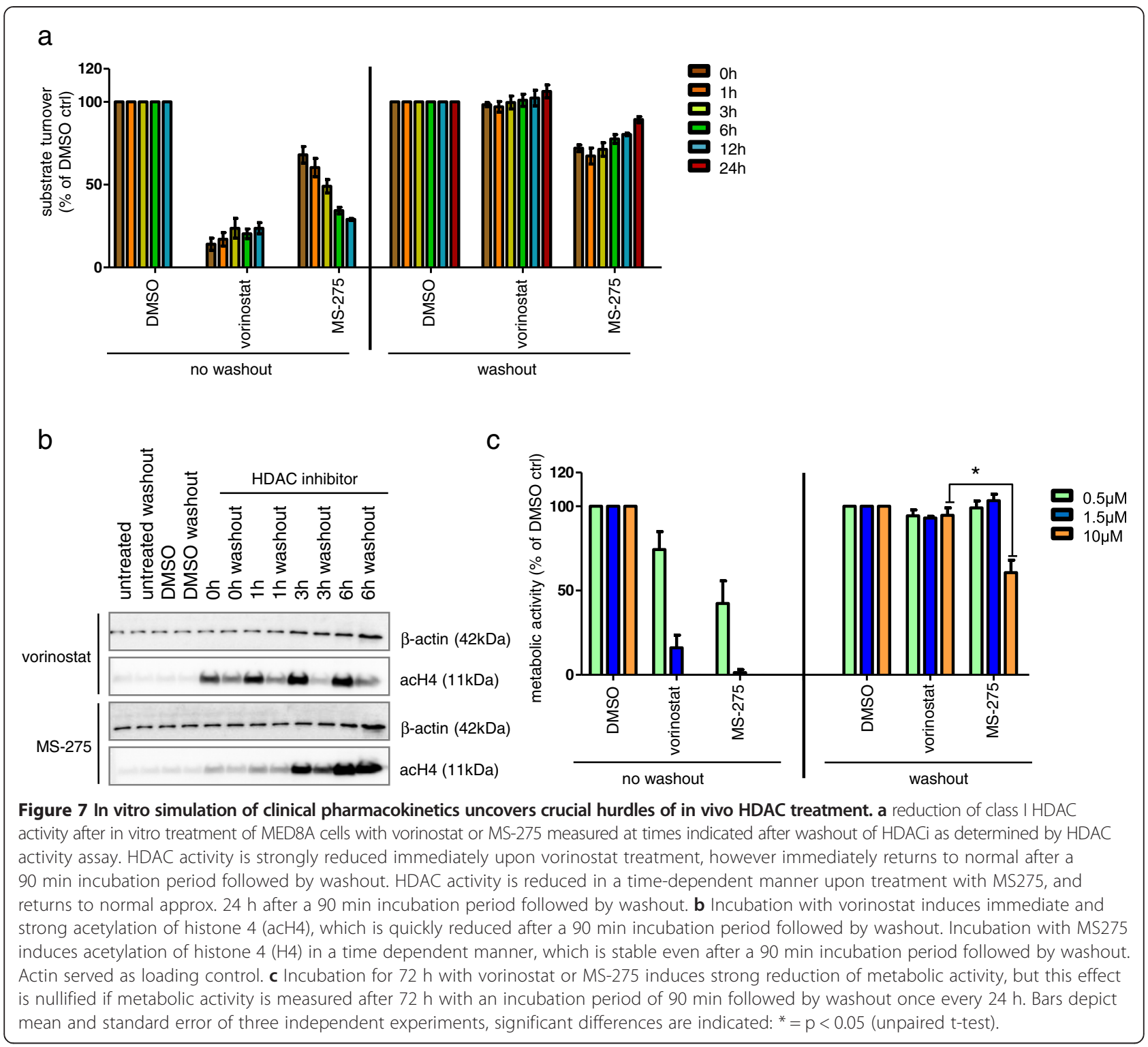

suggest that the inhibition of class IIa enzymatic activity clearly did not confer the same biological effect as the reduction of HDAC5 or HDAC9 protein, suggesting that the enzymatic activity is not the main mechanism for the oncogenic effects of HDAC5 or 9 in MB cells. In contrast, inhibition of class I HDACs elicited a strong response, especially in $M Y C$ amplified cell lines. The enzymatic activity of class I and IIa HDACs therefore plays very divergent roles in MB biology. Indeed, a tyrosine residue in the catalytic site of class I HDACs potentiates the lysine deacetylation activity acting as a transition stabilizer [51]. Due to a highly conserved mutation in the catalytic site of vertebrate class IIa HDACs, switching this tyrosine to a histidine residue, the deacetylating activity of class IIa HDACs on histone proteins is reduced more than a 1000-fold [52]. The repressive effect of class IIa HDACs on gene expression therefore appears to be largely independent of their catalytic activity on histone proteins. This surprising finding is further emphasized by studies showing that a splice variant of HDAC9 lacking the catalytic HDAC domain represses the expression of MEF2 target genes just as effectively as wild-type HDAC9 protein [53]. Finally it is being discussed that class IIa HDACs might play an important role in signal transduction independently of their enzymatic activity, either by bromodomain functioning as readers of epigenetic marks [41], or by shuttling between the nucleus and the cytoplasm [54] as has been shown for HDAC5 [55] and HDAC7 [56], and this could well be true for HDAC5 and 9 in MB.

To verify target presence and elucidate the class I HDACs involved in MB biology, we carried out expression analyses and found class I HDAC2 to be the most 
strongly overexpressed in $\mathrm{MB}$ in general [30] and in the three MB subgroups $\mathrm{SHH}$, group 3 and group 4 (associated with unfavourable or high risk) in particular. Our results indicate that $M Y C$ amplified cell lines have higher sensitivity to $\mathrm{HDACi}$, that comprise class I HDACs 1,2 and 3 in their inhibitory profile, than $M Y C$ single copy cell lines. A previous report studying the effect of the HDACi depsipetide (FK228), which most potently inhibits all class I HDACs, demonstrated that the tumor most sensitive to depsipeptide treatment tested (a CNS-PNET) had the highest expression of $H D A C 2$ relative to $H D A C 1$, and 3-7 [57]. Furthermore, $M Y C$ amplification is a hallmark of Group $3 \mathrm{MB}$, and importantly the transcription factor cMYC has been described to govern the transcription of $H D A C 2$ [58]. We have previously shown that the epigenetic regulation of miR-183 in neuroblastoma involves MYCN and HDAC2 in the same complex [27]. Based on these findings and consistent with our data, showing a significantly increased sensitivity for class I HDAC inhibiting agents in $M Y C$ amplified and HDAC2 overexpressing cell lines, the treatment of $M Y C$ amplified MB with HDAC inhibitors comprising class I HDACs in their inhibitory profile seems to be promising. Future studies should aim at the elucidation of the molecular interactions of cMYC and HDAC2, such as protein-protein interactions, feedback loops, and non-histone lysine deacetylation, governing the susceptibility of $M Y C$ amplified MB to HDACi.

Finally, whether HDACis will be efficacious for the treatment of solid tumors is still under debate. Many trials have failed to show meaningful response of solid tumors to HDACis [44] [45-48]. The root of failure to translate preclinical findings in general has been extensively discussed [59-61]. In general, insufficient pharmacological modeling of the clinical situation in terms of drugs concentrations and kinetics are the primarily criticized factors [61]. Detailed recommendations to improve the predictive value of pre-clinical cancer studies have been developed [60], which include the use of appropriate models, and understanding of the clinical reality, i.e. knowledge of the limitations of pre-clinical experimental settings. Analysis of the models used in our studies confirmed the faithful recapitulation of the patients' tumors by the Group 3 cell lines used in our study, as evidenced by $M Y C$ amplification, and $M Y C$ and $H D A C 2$ expression analysis. To emulate in vitro the drug concentrations present in patients when treated with HDACis, we mimicked the clinical situation with appropriately low HDACi concentrations as well as washout experiments. Our results suggest that several reasons contribute to the failure of HDACis in the clinic despite their promising in vitro results. First, in the absence of a predictive biomarker, trial cohorts have been poorly pre-selected for patients responding with high sensitivity to HDACi treatment, suggesting the lack of efficacy. The most promising predictive biomarker identified in post-hoc analyses to date is IHC for HR23B, which has been shown to be a positive predictive marker for vorinostat in patients with cutaneous T-cell lymphoma [62] and for belinostat (PXD101) in patients with hepatocellular carcinoma [63]. We here validate $M Y C$ amplification as a predictive and routinely applicable clinical biomarker for HDACi sensitivity of medulloblastoma patients. Second, HDACis have a very short inhibitory effect on HDACs when present only a fraction of a day. As this is the case in patients, but not in cell culture, both preand clinical studies need to recognize clinical as opposed to cell culture conditions, and subsequently of the limits of pre-clinical data. Pre-clinical studies need to investigate conditions present in patients, as performed in our washout experiments, and especially pay attention to the lifetime of the drug-target complex [64], as well use adequate and informative readouts [65]. New dosing schedules could well be tested under these conditions, before being translated into the clinical setting. The difference of the half-life of the drug-target complex between vorinostat and MS-275 indicates that the lifetime of the drug-target complex is at least partially determined by the molecular set up of the inhibitory agent [64]. The development of novel agents with increased half-life of the drug-target complex, such as panobinostat, could well be a promising strategy. On the clinical side, studies involving HDACis should demonstrate on target activity in tumor tissue in addition to simply monitoring drug levels and histone acetylation in PBMCs as a surrogate), and possibly develop novel dosing and/or application schedules, such as oral vs. intravenous application, extended release or infusion over several hours, multiple dosing with lower doses etc.

\section{Conclusions}

In summary, we conclude, that i) class I HDACs in general and HDAC2 in particular are a valid target in Group $3 \mathrm{MB}$, ii) $M Y C$ amplified $\mathrm{MB}$ are more sensitive to HDACi than $M Y C$ non-amplified $M B$ and thus $M Y C$ amplification could serve as a positive predictive marker for HDACi treatment, and iii) that both inhibitory profiles and binding kinetics of compounds are of major importance when designing clinical trials using HDACis.

\section{Additional files}

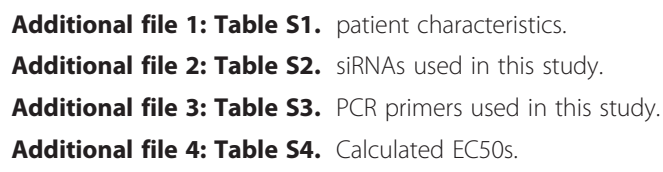

\section{Competing interests}

RM has financial interests in SHAPE Pharmaceuticals and Acetylon

Pharmaceuticals. He is also the inventor on IP licensed to these two entities. RM's interests were reviewed and are managed by Massachusetts General Hospital and Partners HealthCare in accordance with their conflict of interest policies. 


\section{Authors' contributions}

JE conceived and carried out experiments, analyzed data and wrote the manuscript. IO, OW and TM conceived experiments and wrote the manuscript. RM conceived experiments and analyzed data. AK and AvD conceived and carried out experiments, and analyzed data. MK, SMP, TH analyzed data and worte the manuscript. JK, FS, ML, HED and AEK conceived experiments. CK carried out experiments and analyzed data. All authors read and approved the final manuscript.

\section{Acknowledgements}

This work was supported by the MYCNet (BMBF), and the German Childhood Cancer Foundation (Deutsche Kinderkrebsstiftung). JE was supported by Talents in Medicine program of University Hospital Heidelberg and by The German National Academic Foundation (Studienstiftung des deutschen Volkes). IO was supported by the BMWi through SME to IO und DFG (OE 542/2-1) 2014 to IO. RM was supported by the National Institute of Health (P50CA086355).

\section{Author details}

${ }^{1}$ Clinical Cooperation Unit Pediatric Oncology (G340), German Cancer Research Center (DKFZ), Im Neuenheimer Feld 280, 69120 Heidelberg, Germany. ${ }^{2}$ Center for Systems Biology, Massachusetts General Hospital, Boston, MA 02114, USA. ${ }^{3}$ The Broad Institute of Harvard and MIT, Cambridge, Massachusetts 02142, USA. ${ }^{4}$ Department of Neuropathology, University Hospital Heidelberg, Im Neuenheimer Feld 224, 69120 Heidelberg, Germany ${ }^{5}$ Clinical Cooperation Unit Neuropathology (G380), German Cancer Research Center (DKFZ), and German Cancer Consortium (DKTK), Heidelberg, Germany. ${ }^{6}$ Division of Pediatric Neurooncology (B062), German Cancer Research Center (DKFZ), Heidelberg, Germany, and German Cancer Consortium (DKTK), Heidelberg, Germany. ${ }^{7}$ German Cancer Consortium (DKTK), Heidelberg, Germany. ${ }^{8}$ Division of Biostatistics (C060), German Cancer Research Center (DKFZ), Heidelberg, Germany. ${ }^{9}$ Section of Pediatric Brain Tumors, Department of Pediatric Oncology, Hematology and Immunology, University Hospital Heidelberg, Im Neuenheimer Feld 430, 69120 Heidelberg, Germany. ${ }^{10}$ Department of Pediatric Hematology, Oncology and Bone Marrow Transplantation, Charité - University Medicine Berlin, CVK, CC17, Augustenburger Platz 1, 13353 Berlin, Germany.

\section{Received: 12 March 2015 Accepted: 12 March 2015}

\section{Published online: 03 April 2015}

\section{References}

1. Ostrom QT, Gittleman H, Liao P, Rouse C, Chen Y, Dowling J, Wolinsky Y, Kruchko C, Barnholtz-Sloan J (2014) CBTRUS Statistical Report: Primary Brain and Central Nervous System Tumors Diagnosed in the United States in 2007-2011. Neuro-Oncology 16 Suppl 4:iv1-iv63, doi: 10.1093/neuonc/nou223

2. Kaatsch P, Spix C (2013) German Childhood Cancer Registry - Report 2012 (1980-2012), Institute of Medical Biostatistics, Epidemiology and Informatics (IMBEI) at the University Medical Center of the Johannes Gutenberg University Mainz

3. Taylor MD, Northcott PA, Korshunov A, Remke M, Cho YJ, Clifford SC, Eberhart CG, Parsons DW, Rutkowski S, Gajjar A, Ellison DW, Lichter P, Gilbertson RJ, Pomeroy SL, Kool M, Pfister SM (2012) Molecular subgroups of medulloblastoma: the current consensus. Acta Neuropathol 123:465-472, doi: 10.1007/s00401-011-0922-z

4. Jones DT, Jager N, Kool M, Zichner T, Hutter B, Sultan M, Cho YJ, Pugh TJ, Hovestadt V, Stutz AM, Rausch T, Warnatz HJ, Ryzhova M, Bender S, Sturm D, Pleier S, Cin H, Pfaff E, Sieber L, Wittmann A, Remke M, Witt H, Hutter S, Tzaridis T, Weischenfeldt J, Raeder B, Avci M, Amstislavskiy V, Zapatka M, Weber UD et al (2012) Dissecting the genomic complexity underlying medulloblastoma. Nature 488:100-105, doi: 10.1038/nature11284

5. Northcott PA, Jones DT, Kool M, Robinson GW, Gilbertson RJ, Cho YJ, Pomeroy SL, Korshunov A, Lichter P, Taylor MD, Pfister SM (2012) Medulloblastomics: the end of the beginning. Nat Rev Cancer 12:818-834, doi: $10.1038 / \operatorname{nrc} 3410$

6. Northcott PA, Korshunov A, Witt H, Hielscher T, Eberhart CG, Mack S, Bouffet E, Clifford SC, Hawkins CE, French P, Rutka JT, Pfister S, Taylor MD (2011) Medulloblastoma comprises four distinct molecular variants. J Clin Onco 29:1408-1414, doi: 10.1200/JCO.2009.27.4324

7. Cho YJ, Tsherniak A, Tamayo P, Santagata S, Ligon A, Greulich H, Berhoukim R, Amani V, Goumnerova L, Eberhart CG, Lau CC, Olson JM, Gilbertson RJ, Gajjar A, Delattre O, Kool M, Ligon K, Meyerson M, Mesirov JP, Pomeroy SL
(2011) Integrative genomic analysis of medulloblastoma identifies a molecular subgroup that drives poor clinical outcome. J Clin Oncol 29:1424-1430, doi: 10.1200/JCO.2010.28.5148

8. Shih DJ, Northcott PA, Remke M, Korshunov A, Ramaswamy V, Kool M, LuU B, Yao Y, Wang X, Dubuc AM, Garzia L, Peacock J, Mack SC, Wu X, Rolider A, Morrissy AS, Cavalli FM, Jones DT, Zitterbart K, Faria CC, Schuller U, Kren L, Kumabe T, Tominaga T, Shin Ra Y, Garami M, Hauser P, Chan JA, Robinson S, Bognar L et al (2014) Cytogenetic prognostication within medulloblastoma subgroups. J Clin Oncol 32:886-896, doi: 10.1200/ JCO.2013.50.9539

9. Kool M, Jones DT, Jager N, Northcott PA, Pugh TJ, Hovestadt V, Piro RM, Esparza LA, Markant SL, Remke M, Milde T, Bourdeaut F, Ryzhova M, Sturm D, Pfaff E, Stark S, Hutter S, Seker-Cin H, Johann P, Bender S, Schmidt C, Rausch T, Shih D, Reimand J, Sieber L, Wittmann A, Linke L, Witt H, Weber UD, Zapatka M et al (2014) Genome sequencing of SHH medulloblastoma predicts genotype-related response to smoothened inhibition. Cancer Cell 25:393-405, doi: 10.1016/j.ccr.2014.02.004

10. Northcott PA, Lee C, Zichner T, Stutz AM, Erkek S, Kawauchi D, Shih DJ, Hovestadt V, Zapatka M, Sturm D, Jones DT, Kool M, Remke M, Cavalli FM, Zuyderduyn S, Bader GD, VandenBerg S, Esparza LA, Ryzhova M, Wang W, Wittmann A, Stark S, Sieber L, Seker-Cin H, Linke L, Kratochwil F, Jager N, Buchhalter I, Imbusch CD, Zipprich G et al (2014) Enhancer hijacking activates GFI1 family oncogenes in medulloblastoma. Nature 511:428-434, doi: 10.1038/nature13379

11. Pugh TJ, Weeraratne SD, Archer TC, Pomeranz Krummel DA, Auclair D, Bochicchio J, Carneiro MO, Carter SL, Cibulskis K, Erlich RL, Greulich H, Lawrence MS, Lennon NJ, McKenna A, Meldrim J, Ramos AH, Ross MG, Russ C, Shefler E, Sivachenko A, Sogoloff B, Stojanov P, Tamayo P, Mesirov JP, Amani V, Teider N, Sengupta S, Francois JP, Northcott PA, Taylor MD et al (2012) Medulloblastoma exome sequencing uncovers subtype-specific somatic mutations. Nature 488:106-110, doi: 10.1038/nature11329

12. Robinson G, Parker M, Kranenburg TA, Lu C, Chen X, Ding L, Phoenix TN, Hedlund E, Wei L, Zhu X, Chalhoub N, Baker SJ, Huether R, Kriwacki R, Curley N, Thiruvenkatam R, Wang J, Wu G, Rusch M, Hong X, Becksfort J, Gupta P, Ma J, Easton J, Vadodaria B, Onar-Thomas A, Lin T, Li S, Pounds S, Paugh $S$ et al (2012) Novel mutations target distinct subgroups of medulloblastoma. Nature 488:43-48, doi: 10.1038/nature11213

13. Kool M, Korshunov A, Remke M, Jones DT, Schlanstein M, Northcott PA, Cho YJ, Koster J, Schouten-van Meeteren A, van Vuurden D, Clifford SC, Pietsch T, von Bueren AO, Rutkowski S, McCabe M, Collins VP, Backlund ML, Haberler C, Bourdeaut F, Delattre O, Doz F, Ellison DW, Gilbertson RJ, Pomeroy SL, Taylor MD, Lichter P, Pfister SM (2012) Molecular subgroups of medulloblastoma: an international meta-analysis of transcriptome, genetic aberrations, and clinical data of WNT, SHH, Group 3, and Group 4 medulloblastomas. Acta Neuropathol 123:473-484, doi: 10.1007/s00401-012-0958-8

14. Northcott PA, Shih DJ, Peacock J, Garzia L, Morrissy AS, Zichner T, Stutz AM, Korshunov A, Reimand J, Schumacher SE, Beroukhim R, Ellison DW, Marshall CR Lionel AC, Mack S, Dubuc A, Yao Y, Ramaswamy V, Luu B, Rolider A, Cavalli FM, Wang X, Remke M, Wu X, Chiu RY, Chu A, Chuah E, Corbett RD, Hoad GR, Jackman SD et al (2012) Subgroup-specific structural variation across 1,000 medulloblastoma genomes. Nature 488:49-56, doi: 10.1038/nature11327

15. Jones DT, Northcott PA, Kool M, Pfister SM (2013) The role of chromatin remodeling in medulloblastoma. Brain Pathol 23:193-199, doi: 10.1111/ bpa.12019

16. Dubuc AM, Remke M, Korshunov A, Northcott PA, Zhan SH, Mendez-Lago M, Kool M, Jones DT, Unterberger A, Morrissy AS, Shih D, Peacock J, Ramaswamy V, Rolider A, Wang X, Witt H, Hielscher T, Hawkins C, Vibhakar R, Croul S, Rutka JT, Weiss WA, Jones SJ, Eberhart CG, Marra MA, Pfister SM, Taylor MD (2013) Aberrant patterns of H3K4 and H3K27 histone lysine methylation occur across subgroups in medulloblastoma. Acta Neuropathol 125:373-384, doi: 10.1007/s00401-012-1070-9

17. Hovestadt V, Jones DT, Picelli S, Wang W, Kool M, Northcott PA, Sultan M, Stachurski K, Ryzhova M, Warnatz HJ, Ralser M, Brun S, Bunt J, Jager N, Kleinheinz K, Erkek S, Weber UD, Bartholomae CC, von Kalle C, Lawerenz C, Eils J, Koster J, Versteeg R, Milde T, Witt O, Schmidt S, Wolf S, Pietsch T, Rutkowski S, Scheurlen W et al (2014) Decoding the regulatory landscape of medulloblastoma using DNA methylation sequencing. Nature 510:537-541, doi: 10.1038/nature13268

18. Bolden JE, Peart MJ, Johnstone RW (2006) Anticancer activities of histone deacetylase inhibitors. Nat Rev Drug Discov 5:769-784, doi: 10.1038/nrd2133

19. Lee SJ, Lindsey S, Graves B, Yoo S, Olson JM, Langhans SA (2013) Sonic hedgehog-induced histone deacetylase activation is required for cerebellar 
granule precursor hyperplasia in medulloblastoma. PLoS One 8:e71455, doi: 10.1371/journal.pone.0071455

20. Jaboin J, Wild J, Hamidi H, Khanna C, Kim CJ, Robey R, Bates SE, Thiele CJ (2002) MS-27-275, an Inhibitor of Histone Deacetylase, Has Marked in Vitro and in Vivo Antitumor Activity against Pediatric Solid Tumors. Cancer Res 62:6108-6115

21. Furchert SE, Lanvers-Kaminsky $C$, Juurgens $H$, Jung M, Loidl A, Fruhwald MC (2007) Inhibitors of histone deacetylases as potential therapeutic tools for high-risk embryonal tumors of the nervous system of childhood. Int J Cancer 120:1787-1794, doi: 10.1002/ijc.22401

22. Wegener D, Deubzer HE, Oehme I, Milde T, Hildmann C, Schwienhorst A, Witt O (2008) HKI 46F08, a novel potent histone deacetylase inhibitor, exhibits antitumoral activity against embryonic childhood cancer cells. AntiCancer Drugs 19:849-857, doi: 10.1097/CAD.0b013e32830efbeb

23. Ecke I, Petry F, Rosenberger A, Tauber S, Monkemeyer S, Hess I, Dullin C, Kimmina S, Pirngruber J, Johnsen SA, Uhmann A, Nitzki F, Wojnowski L, Schulz-Schaeffer W, Witt O, Hahn H (2009) Antitumor effects of a combined 5-aza-2'deoxycytidine and valproic acid treatment on rhabdomyosarcoma and medulloblastoma in Ptch mutant mice. Cancer Res 69:887-895, doi: 10.1158/0008-5472.CAN-08-0946

24. Milde T, Lodrini M, Savelyeva L, Korshunov A, Kool M, Brueckner LM, Antunes AS, Oehme I, Pekrun A, Pfister SM, Kulozik AE, Witt O, Deubzer HE (2012) HD-MB03 is a novel Group 3 medulloblastoma model demonstrating sensitivity to histone deacetylase inhibitor treatment. J Neuro-Oncol 110:335-348, doi: 10.1007/s11060-012-0978-1

25. Oehme I, Deubzer HE, Wegener D, Pickert D, Linke JP, Hero B, KoppSchneider A, Westermann F, Ulrich SM, von Deimling A, Fischer M, Witt O (2009) Histone deacetylase 8 in neuroblastoma tumorigenesis. Clin Cancer Res 15:91-99, doi: 10.1158/1078-0432.CCR-08-0684

26. Oehme I, Linke JP, Bock BC, Milde T, Lodrini M, Hartenstein B, Wiegand I, Eckert C, Roth W, Kool M, Kaden S, Grone HJ, Schulte JH, Lindner S, Hamacher-Brady A, Brady NR, Deubzer HE, Witt O (2013) Histone deacetylase 10 promotes autophagy-mediated cell survival. Proc Natl Acad Sci U S A 110:E2592-E2601, doi: 10.1073/pnas.1300113110

27. Lodrini M, Oehme I, Schroeder C, Milde T, Schier MC, Kopp-Schneider A, Schulte JH, Fischer M, De Preter K, Pattyn F, Castoldi M, Muckenthaler MU, Kulozik AE, Westermann F, Witt O, Deubzer HE (2013) MYCN and HDAC2 cooperate to repress miR-183 signaling in neuroblastoma. Nucleic Acids Res 41:6018-6033, doi: 10.1093/nar/gkt346

28. Fabian J, Lodrini M, Oehme I, Schier MC, Thole TM, Hielscher T, KoppSchneider A, Opitz L, Capper D, von Deimling A, Wiegand I, Milde T, Mahlknecht U, Westermann F, Popanda O, Roels F, Hero B, Berthold F, Fischer M, Kulozik AE, Witt O, Deubzer HE (2014) GRHL1 acts as tumor suppressor in neuroblastoma and is negatively regulated by MYCN and HDAC3. Cancer Res 74:2604-2616, doi: 10.1158/0008-5472.CAN-13-1904

29. Milde T, Oehme I, Korshunov A, Kopp-Schneider A, Remke M, Northcott P, Deubzer HE, Lodrini M, Taylor MD, von Deimling A, Pfister S, Witt O (2010) HDAC5 and HDAC9 in medulloblastoma: novel markers for risk stratification and role in tumor cell growth. Clin Cancer Res 16:3240-3252, doi: 10.1158/ 1078-0432.CCR-10-0395

30. Ecker J, Witt O, Milde T (2013) Targeting of histone deacetylases in brain tumors. CNS Oncol 2:359-376, doi: 10.2217/cns.13.24

31. Tessier P, Smil DV, Wahhab A, Leit S, Rahil J, Li Z, Deziel R, Besterman JM (2009) Diphenylmethylene hydroxamic acids as selective class lla histone deacetylase inhibitors. Bioorg Med Chem Lett 19:5684-5688, doi: 10.1016/j. bmcl.2009.08.010

32. Bai AH, Milde T, Remke M, Rolli CG, Hielscher T, Cho YJ, Kool M, Northcott PA, Jugold M, Bazhin AV, Eichmuller SB, Kulozik AE, Pscherer A, Benner A, Taylor MD, Pomeroy SL, Kemkemer R, Witt O, Korshunov A, Lichter P, Pfister SM (2012) MicroRNA-182 promotes leptomeningeal spread of non-sonic hedgehog-medulloblastoma. Acta Neuropathol 123:529-538, doi: 10.1007/ s00401-011-0924-x

33. Schmitt M, Pawlita M (2009) High-throughput detection and multiplex identification of cell contaminations. Nucleic Acids Res 37:e119, doi: 10.1093/nar/gkp581

34. Northcott PA, Shih DJ, Remke M, Cho YJ, Kool M, Hawkins C, Eberhart CG, Dubuc A, Guettouche T, Cardentey Y, Bouffet E, Pomeroy SL, Marra M, Malkin D, Rutka JT, Korshunov A, Pfister S, Taylor MD (2012) Rapid, reliable, and reproducible molecular sub-grouping of clinical medulloblastoma samples. Acta Neuropathol 123:615-626, doi: 10.1007/s00401-011-0899-7

35. Hovestadt V, Remke M, Kool M, Pietsch T, Northcott PA, Fischer R, Cavalli FM, Ramaswamy V, Zapatka M, Reifenberger G, Rutkowski S, Schick M,
Bewerunge-Hudler M, Korshunov A, Lichter P, Taylor MD, Pfister SM, Jones DT (2013) Robust molecular subgrouping and copy-number profiling of medulloblastoma from small amounts of archival tumour material using high-density DNA methylation arrays. Acta Neuropathol 125:913-916, doi: 10.1007/s00401-013-1126-5

36. Witt H, Mack SC, Ryzhova M, Bender S, Sill M, Isserlin R, Benner A, Hielscher T, Milde T, Remke M, Jones DT, Northcott PA, Garzia L, Bertrand KC, Wittmann A, Yao Y, Roberts SS, Massimi L, Van Meter T, Weiss WA, Gupta N, Grajkowska W, Lach B, Cho YJ, von Deimling A, Kulozik AE, Witt O, Bader GD, Hawkins CE, Tabori U et al (2011) Delineation of two clinically and molecularly distinct subgroups of posterior fossa ependymoma. Cancer Cell 20:143-157, doi: 10.1016/j.ccr.2011.07.007

37. Milde T, Hielscher T, Witt H, Kool M, Mack SC, Deubzer HE, Oehme I, Lodrini M, Benner A, Taylor MD, von Deimling A, Kulozik AE, Pfister SM, Witt O, Korshunov A (2012) Nestin expression identifies ependymoma patients with poor outcome. Brain Pathol 22:848-860, doi: 10.1111/j.1750-3639.2012.00600.x

38. Rizzardi AE, Johnson AT, Vogel Rl, Pambuccian SE, Henriksen J, Skubitz AP, Metzger GJ, Schmechel SC (2012) Quantitative comparison of immunohistochemical staining measured by digital image analysis versus pathologist visual scoring. Diagn Pathol 7:42, doi: 10.1186/1746-1596-7-42

39. Pfister S, Remke M, Benner A, Mendrzyk F, Toedt G, Felsberg J, Wittmann A, Devens F, Gerber NU, Joos S, Kulozik A, Reifenberger G, Rutkowski S, Wiestler OD, Radlwimmer B, Scheurlen W, Lichter P, Korshunov A (2009) Outcome prediction in pediatric medulloblastoma based on DNA copynumber aberrations of chromosomes $6 \mathrm{q}$ and $17 \mathrm{q}$ and the MYC and MYCN loci. J Clin Oncol 27:1627-1636, doi: 10.1200/JCO.2008.17.9432

40. Milde T, Kleber S, Korshunov A, Witt H, Hielscher T, Koch P, Kopp HG, Jugold M, Deubzer HE, Oehme I, Lodrini M, Grone HJ, Benner A, Brustle O, Gilbertson RJ, von Deimling A, Kulozik AE, Pfister SM, Martin-Villalba A, Witt O (2011) A novel human high-risk ependymoma stem cell model reveals the differentiation-inducing potential of the histone deacetylase inhibitor Vorinostat. Acta Neuropathol 122:637-650, doi: 10.1007/s00401-011-0866-3

41. Bradner JE, West N, Grachan ML, Greenberg EF, Haggarty SJ, Warnow T, Mazitschek R (2010) Chemical phylogenetics of histone deacetylases. Nat Chem Biol 6:238-243, doi: 10.1038/nchembio.313

42. Fakih MG, Fetterly G, Egorin MJ, Muindi JR, Espinoza-Delgado I, Zwiebel JA, Litwin A, Holleran JL, Wang K, Diasio RB (2010) A phase I, pharmacokinetic, and pharmacodynamic study of two schedules of vorinostat in combination with 5-fluorouracil and leucovorin in patients with refractory solid tumors. Clin Cancer Res 16:3786-3794, doi: 10.1158/1078-0432.CCR-10-0547

43. Kummar S, Gutierrez M, Gardner ER, Donovan E, Hwang K, Chung EJ, Lee MJ, Maynard K, Kalnitskiy M, Chen A, Melillo G, Ryan QC, Conley B, Figg WD, Trepel JB, Zwiebel J, Doroshow JH, Murgo AJ (2007) Phase I trial of MS-275, a histone deacetylase inhibitor, administered weekly in refractory solid tumors and lymphoid malignancies. Clin Cancer Res 13:5411-5417, doi: 10.1158/1078-0432.CCR-07-0791

44. Rathkopf DE, Picus J, Hussain A, Ellard S, Chi KN, Nydam T, Allen-Freda E, Mishra KK, Porro MG, Scher HI, Wilding G (2013) A phase 2 study of intravenous panobinostat in patients with castration-resistant prostate cancer. Cancer Chemother Pharmacol 72:537-544, doi: 10.1007/s00280-013-2224-8

45. Sherman EJ, Su YB, Lyall A, Schoder H, Fury MG, Ghossein RA, Haque S, Lisa D, Shaha AR, Tuttle RM, Pfister DG (2013) Evaluation of romidepsin for clinical activity and radioactive iodine reuptake in radioactive iodinerefractory thyroid carcinoma. Thyroid 23:593-599, doi: 10.1089/thy.2012.0393

46. Vansteenkiste J, Van Cutsem E, Dumez H, Chen C, Ricker JL, Randolph SS, Schoffski P (2008) Early phase II trial of oral vorinostat in relapsed or refractory breast, colorectal, or non-small cell lung cancer. Investig New Drugs 26:483-488, doi: 10.1007/s10637-008-9131-6

47. Woyach JA, Kloos RT, Ringel MD, Arbogast D, Collamore M, Zwiebel JA, Grever M, Villalona-Calero M, Shah MH (2009) Lack of therapeutic effect of the histone deacetylase inhibitor vorinostat in patients with metastatic radioiodine-refractory thyroid carcinoma. J Clin Endocrinol Metab 94:164-170, doi: 10.1210/jc.2008-1631

48. Molife LR, de Bono JS (2011) Belinostat: clinical applications in solid tumors and lymphoma. Expet Opin Investig Drugs 20:1723-1732, doi: 10.1517/ 13543784.2011.629604

49. Kelly WK, O'Connor OA, Krug LM, Chiao JH, Heaney M, Curley T, MacGregore-Cortelli B, Tong W, Secrist JP, Schwartz L, Richardson S, Chu E, Olgac S, Marks PA, Scher H, Richon VM (2005) Phase I study of an oral histone deacetylase inhibitor, suberoylanilide hydroxamic acid, in patients with advanced cancer. J Clin Oncol 23:3923-3931, doi: 10.1200/ JCO.2005.14.167 
50. Chou CJ, Herman D, Gottesfeld JM (2008) Pimelic diphenylamide 106 is a slow, tight-binding inhibitor of class I histone deacetylases. J Biol Chem 283:35402-35409, doi: 10.1074/jbc.M807045200

51. Lahm A, Paolini C, Pallaoro M, Nardi MC, Jones P, Neddermann P, Sambucin S, Bottomley MJ, Lo Surdo P, Carfi A, Koch U, De Francesco R, Steinkuhler C, Gallinari P (2007) Unraveling the hidden catalytic activity of vertebrate class Ila histone deacetylases. Proc Natl Acad Sci U S A 104:17335-17340, doi: 10.1073/pnas.0706487104

52. Jones $P$, Altamura $S$, De Francesco R, Gallinari P, Lahm A, Neddermann P Rowley M, Serafini S, Steinkuhler C (2008) Probing the elusive catalytic activity of vertebrate class lla histone deacetylases. Bioorg Med Chem Lett 18:1814-1819, doi: 10.1016/j.bmcl.2008.02.025

53. Zhang CL, McKinsey TA, Lu JR, Olson EN (2001) Association of COOHterminal-binding protein (CtBP) and MEF2-interacting transcription repressor (MITR) contributes to transcriptional repression of the MEF2 transcription factor. J Biol Chem 276:35-39, doi: 10.1074/jbc.M007364200

54. Gregoire S, Yang XJ (2005) Association with class Ila histone deacetylases upregulates the sumoylation of MEF2 transcription factors. Mol Cell Biol 25:2273-2287, doi: 10.1128/MCB. 25.6.2273-2287.2005

55. McKinsey TA, Zhang CL, Lu J, Olson EN (2000) Signal-dependent nuclear export of a histone deacetylase regulates muscle differentiation. Nature 408:106-111, doi: 10.1038/35040593

56. Kao HY, Verdel A, Tsai CC, Simon C, Juguilon H, Khochbin S (2001) Mechanism for nucleocytoplasmic shuttling of histone deacetylase 7. J Bio Chem 276:47496-47507, doi: 10.1074/jbc.M107631200

57. Graham C, Tucker C, Creech J, Favours E, Billups CA, Liu T, Fouladi M, Freeman BB 3rd, Stewart CF, Houghton PJ (2006) Evaluation of the antitumor efficacy, pharmacokinetics, and pharmacodynamics of the histone deacetylase inhibitor depsipeptide in childhood cancer models in vivo. Clin Cancer Res 12:223-234, doi: 10.1158/1078-0432.CCR-05-1225

58. Bhandari DR, Seo KW, Jung JW, Kim HS, Yang SR, Kang KS (2011) The regulatory role of C-MYC on HDAC2 and PCG expression in human multipotent stem cells. J Cell Mol Med 15:1603-1614, doi: 10.1111/j.1582 4934.2010.01144.x

59. Prinz F, Schlange T, Asadullah K (2011) Believe it or not: how much can we rely on published data on potential drug targets? Nat Rev Drug Discov 10:712, doi: 10.1038/nrd3439-c1

60. Begley CG, Ellis LM (2012) Drug development: Raise standards for preclinical cancer research. Nature 483:531-533, doi: 10.1038/483531a

61. Smith MA, Houghton P (2013) A proposal regarding reporting of in vitro testing results. Clin Cancer Res 19:2828-2833, doi: 10.1158/1078-0432.CCR-13-0043

62. Khan O, Fotheringham S, Wood V, Stimson L, Zhang C, Pezzella F, Duvic M, Kerr DJ, La Thangue NB (2010) HR23B is a biomarker for tumor sensitivity to HDAC inhibitor-based therapy. Proc Natl Acad Sci U S A 107:6532-6537, doi: 10.1073/pnas.0913912107

63. Yeo W, Chung HC, Chan SL, Wang LZ, Lim R, Picus J, Boyer M, Mo FK, Koh J, Rha SY, Hui EP, Jeung HC, Roh JK, Yu SC, To KF, Tao Q, Ma BB, Chan AW, Tong JH, Erlichman C, Chan AT, Goh BC (2012) Epigenetic therapy using belinostat for patients with unresectable hepatocellular carcinoma: a multicenter phase $\mathrm{I} / \|$ study with biomarker and pharmacokinetic analysis of tumors from patients in the Mayo Phase II Consortium and the Cancer Therapeutics Research Group. J Clin Oncol 30:3361-3367, doi: 10.1200/JCO.2011.41.2395

64. Lu H, Tonge PJ (2010) Drug-target residence time: critical information for lead optimization. Curr Opin Chem Biol 14:467-474, doi: 10.1016/j.cbpa.2010.06.176

65. Lauffer BE, Mintzer R, Fong R, Mukund S, Tam C, Zilberleyb I, Flicke B, Ritscher A, Fedorowicz G, Vallero R, Ortwine DF, Gunzner J, Modrusan Z, Neumann L, Koth CM, Lupardus PJ, Kaminker JS, Heise CE, Steiner P (2013) Histone deacetylase (HDAC) inhibitor kinetic rate constants correlate with cellular histone acetylation but not transcription and cell viability. J Biol Chem 288:26926-26943, doi: 10.1074/jbc.M113.490706

\section{Submit your next manuscript to BioMed Central and take full advantage of:}

- Convenient online submission

- Thorough peer review

- No space constraints or color figure charges

- Immediate publication on acceptance

- Inclusion in PubMed, CAS, Scopus and Google Scholar

- Research which is freely available for redistribution

Submit your manuscript at www.biomedcentral.com/submit 